\title{
Royal Saints, Artistic Patronage, and Self-representation among Hungarian Noblemen
}

\author{
D. Gh. Năstăsoiu
}

For citation: Năstăsoiu D.Gh. Royal Saints, Artistic Patronage, and Self-representation among Hungarian Noblemen. Vestnik of Saint Petersburg University. History, 2021, vol.66, issue 3, pp. 810827. https://doi.org/10.21638/11701/spbu02.2021.308

During the 1401-1403 political crisis in the Kingdom of Hungary, the magnates who were hostile to the ruling King Sigismund of Luxemburg and supported instead the Angevin King Ladislas of Naples deployed a wide range of propaganda tools for proving the legitimacy of their political cause. In a previous study published in this journal (Vestnik of SPbSU. History, 2021, vol.66, issue 1, pp. 179-192), I have focused on the Hungarian noblemen's an-

Dragos, Gh. Năstăsoiu - PhD, Research Fellow, National Research University Higher School of Economics, 20, Myasnitskaya ul., Moscow, 101000, Russian Federation; MECERN Researcher, Central European University, 9, Nádor, Budapest, H-1051, Hungary / 51 Quellenstraße, Vienna, A-1100, Austria; dragos_nastasoiu@yahoo.com, dragos.nastasoiu@hse.ru

Драгош Г.Настасою - PhD, науч. сотр., Национальный исследовательский университет «Высшая школа экономики», Российская Федерация, 101000, Москва, ул. Мясницкая, 20; исследовательский проект MECERN при Центрально-Европейском университете, Венгрия, Н-1051, Будапешт, ул. Надор, 9 / Австрия, А-1100, Вена, Квелленштрассе, 51; dragos_nastasoiu@yahoo.com, dragos.nastasoiu@hse.ru

The results of the project "Models of Representation of the Past in the Middle Ages and Early Modern Period" carried out within the framework of the Basic Research Program at the National Research University Higher School of Economics (HSE) in 2019 are presented in this work. A version of this paper was read at the Fourth Medieval Workshop in Rijeka, Faculty of Humanities and Social Sciences of the University of Rijeka, 30-31 May 2019. I am grateful to the organizers, Dr. Kosana Jovanović and Dr. Suzana Miljan, for this opportunity.

В статье использованы результаты проекта «Модели представления прошлого в Средние века и раннее Новое время», выполненного в рамках Программы фундаментальных исследований НИУ ВШЭ в 2019 г. Версия данной публикации была прочитана на Четвертом семинаре средневековых исследований на факультете гуманитарных и социальных наук Университета Риеки, 30-31 мая 2019 г. Я благодарен организаторам семинара доктору Косане Йованович и доктору Сузане Милян за эту возможность.

(C) St. Petersburg State University, 2021 
ti-royal propaganda through the utilizing of political and spiritual symbols (i.e., the Holy Crown of Hungary and the cult, relics, and visual representations of St. Ladislas), symbolic actions (coronations and oath-swearing on holy relics), and heraldic self-representation (the Árpádian double cross). The present study approaches the same topic of anti-royal propaganda in the troubled political context of the early $15^{\text {th }}$ century, but from the perspective of the elites' self-representation strategies via the cult of Hungarian royal saints, artistic patronage, and heraldic self-representation. The two leaders of the anti-royal movement, Archbishop of Esztergom John Kanizsai and Palatine of Hungary Detre Bebek, repeatedly commissioned works of art (i.e., seals, stained-glass windows, and wall paintings) which featured prominently the images of the three Holy Kings of Hungary (Sts Stephen, Emeric, and Ladislas) or displayed the realm's coat of arms (the Árpádian two-barred cross). The reliance of John Kanizsai and Detre Bebek on the cults and images of the patron saints of the country blended harmoniously the commissioners' personal piety with their political ambitions. In the context of the early- $15^{\text {th }}$ century political crisis, the appropriation of the ideal figures of the sancti reges Hungariae became the driving force behind the Hungarian noblemen's political cause.

Keywords: St. Ladislas, sancti reges Hungariae, medieval Hungary, cult of royal saints, medieval seals, medieval mural painting, heraldry, elite self-representation, anti-royal propaganda, Hungarian political crisis of 1401-1403.

\section{Святые короли, художественный патронаж и самопрезентация венгерской знати}

\section{Д. Г. Настасою}

Для цитирования: Năstăsoiu D. Gh. Royal Saints, Artistic Patronage, and Self-representation among Hungarian Noblemen // Вестник Санкт-Петербургского университета. История. 2021. Т.66. Вып. 3. С. 810-827. https://doi.org/10.21638/11701/spbu02.2021.308

Во время политического кризиса 1401-1403 гг. в Венгерском королевстве магнаты, враждебно относившиеся к правящему королю Сигизмунду Люксембургскому и поддерживающие неаполитанского короля Ладислава Анжуйского, использовали широкий спектр средств пропаганды, доказывающих легитимность их политической позиции. В нашем предыдущем исследовании (см.: Вестник СПбГУ. История. 2021. Т. 66. Вып. 1. С.179-192) мы сосредоточились на пропаганде венгерской знатью антикоролевских идей посредством использования политических и духовных символов (Священная венгерская корона, реликвии и образы св. Ласло), символических действий (коронации и присяги на святых мощах) и геральдических изображений (двойной крест Арпадов). Настоящая статья рассматривает ту же тему антикоролевской пропаганды в бурный период начала XV столетия в стратегиях самопрезентации знати, отраженных в почитании венгерских королевских святых, художественном покровительстве и выборе геральдической символики. Два лидера антикоролевского движения, архиепископ Эстергома Янош Канижай и палатин Венгрии Детре Бебек, неоднократно заказывали произведения искусства (например, печати, витражи, росписи стен) с изображениями святых венгерских королей (Стефан, Эмерик и Ласло) или герба королевства (крест Арпадов с двумя перемычками). Почитающие святых покровителей страны Янош Канижай и Детре Бебек гармонично сочетали благочестие с амбициями. В контексте кризиса начала XV в. использование идеальных образов sancti reges Hungariae стало движущей политической силой для венгерской знати.

Ключевые слова: святой Ласло (Владислав), sancti reges Hungariae, средневековая Венгрия, культ святых королей, средневековые печати, средневековая стенопись, геральдика, самопрезентация элит, антикоролевская пропаганда, политический кризис 14011403 гг. 
During the political crisis of 1401-1403, the Hungarian noblemen who were hostile to the ruling king, Sigismund of Luxemburg (r. 1387-1437), and supported instead another claimant to the Hungarian throne, the Angevin King Ladislas of Naples (r. 1386-1414), utilized a wide range of propaganda tools meant to prove the legitimacy of their anti-royal actions. They resorted constantly to important spiritual and political symbols associated with the realm, such as the Holy Crown of Hungary, the heraldry of the country, or the cult and relics of St. Ladislas. For instance, when forming the Council of the Holy Crown in May 1401, the Hungarian magnates endowed it with a seal whose heraldic shield decorated with the Árpádian double cross symbolized the realm rather than the ruler, and thus asserted the sovereignty of their noble commonwealth to the detriment of the changing person of the king. In order to attain the general good of the realm as they envisioned it, they engaged in military combats against the contested king fighting under the heraldic banner of King Ladislas of Naples. The propagandistic usage of heraldic, political, and spiritual symbols was further reinforced by their involvement into elaborated rituals and symbolic actions, such as coronations and oath-swearing on holy relics. For instance, during a brief moment of reconciliation between the two political parties, the contested King Sigismund swore a solemn oath on the Wood of the Holy Cross and promised to comply with the magnates' demands. Before 5 August 1403, in St. Anastasia Cathedral in Zadar, the Archbishop of Esztergom John Kanizsai crowned Ladislas of Naples King of Hungary, Dalmatia, and Croatia, but this gesture was counterbalanced by King Sigismund's own symbolic coronation, which was performed instead with the sole legitimate object, namely, St. Stephen's Holy Crown. Finally, on Christmas Eve 1402, the Hungarian noblemen gathered in the Cathedral of Nagyvárad, where the tomb of the Holy King and Knight Ladislas I was located, and proclaimed their allegiance to King Ladislas of Naples by swearing an oath on the relics of the holy king. Incorporated in such a religious and political ritual, the human-shaped bust reliquary of St. Ladislas signaled that the holy king himself took part in these symbolic actions, overseeing and sanctioning them. The symbolic engagement of St. Ladislas in this ritual was meant to activate the link between secular and religious spheres, the performers hoping to attract the divine approval in this way. Therefore, during the 1401-1403 political crisis, the Hungarian noblemen appropriated with consistency the ideal figure of St. Ladislas, who became the driving force behind their political cause and continued to be a powerful symbol of the country.

This appropriation of St. Ladislas' figure occurred also at the level of the artistic and religious patronage of the main actors of the early- $15^{\text {th }}$ century political crisis, and it is the aim of this second essay to highlight how these noblemen's personal piety was exploited in favor of their political agenda. On the one hand, their artistic and religious patronage is characterized by a constant reliance on the cults and images of St. Ladislas and the other two sancti reges Hungariae as a means of expressing political and propagandistic messages. On the other hand, it is distinguished by the incorporation - for political and self-representational purposes - of the realm's heraldry into the personal coats of arms of these Hungarian noblemen. However, before examining in detail how the personal piety of these Hungarian barons involved in the early- $15^{\text {th }}$ century anti-royal movement was instrumentalised for political purposes, it is necessary to outline the cults and iconography of St. Ladislas and the other two Hungarian holy kings, namely, St. Stephen and St. Emeric.

Having reigned between 1077 and 1095, King Ladislas I was canonized in 1192 at the initiative of King Béla III (r. 1172-1196), his cult centering from its outset on the holy 
ruler's exceptional moral virtues and physical excellence ${ }^{1}$. Labeled by liturgical texts as columpna milicie christianae (pillar of Christian militia) and defensor indefessus et athleta patriae (invincible defender and athlete of the fatherland), St. Ladislas soon became an ideal knight whose conduct was guided by four key-virtues: veritas (truthfulness), providencia (foresight), humanitas (humanity), and strenuitas (energy) ${ }^{2}$. In the person of St. Ladislas, physical excellence and profusion of corporeal gifts blended harmoniously with the noblesse of birth and of character; the idea of physical beauty conceived as a manifestation of good was an important chivalric virtue for that matter ${ }^{3}$. These chief traits made the ideal figure of St. Ladislas extremely appealing to Hungarian noblemen, who thus commissioned the decoration of their churches with the pictorial cycle of the holy king and knight ${ }^{4}$. Preserved in many religious edifices across medieval Hungary, this visual narrative focuses on one of the most chivalric exploits in the holy knight's life when, during the confrontation between the Hungarian and Cuman armies, St. Ladislas rescued a beautiful Hungarian maiden from her evil pagan abductor. Replete with popular motifs coming from medieval chivalric or heroic romances, this pictorial narrative proliferated against the background of the knightly culture that was adopted by the Hungarian royal court and was particularly encouraged by the Angevin Kings of Hungary and, later on, by

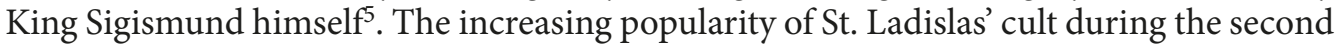
half of the $14^{\text {th }}$ century led to his final transformation into a powerful symbol of the country. This was the moment when King Louis I the Great of Anjou (r. 1342-1382) replaced the effigy of St. John the Baptist on the new golden florin he issued with the full standing figure of St. Ladislas, represented as a haloed and crowned king holding the globus cruciger and a battle-axe as his attributes ${ }^{6}$. Later on, the double majestic seal of Queen Mary of Anjou (r. 1382-1395), which she used throughout her sole reign (1382-1386), featured on its reverse the bust of St. Ladislas holding his usual attributes (i.e., battle-axe and globus cruciger) and hovering over the heraldic shield decorated with the Árpádians' two-barred cross. In this hypostasis, St. Ladislas was explicitly shown as the patron saint of the realm,

${ }^{1}$ For a bibliographical overview up to 2007 of St. Ladislas' cult, see: Kerny T. Szent László tiszteletének kutatástörténete (1977-2007) // Arrabona. 2008. Vol.46, iss. 1. P. 15-35. - After this date, see especially: Klaniczay G. A Szent László kultusz kialakulása // Nagyvárad és Bihar a korai középkorban. Tanulmányok Biharország történetéről. Nagyvárad, 2014. P.7-39; Solymosi L. Szent László király sírja, kultusza és szentté avatása // Szent király, lovágkirály. A Szent László-herma és koponyaereklye vizsgálatai. Győr, 2017. P. 16-39.

2 Klaniczay G. Holy Rulers and Blessed Princesses. Dynastic Cults in Medieval Central Europe. Cambridge, 2000. P. 188-189. - For St. Ladislas' cult generally, see also: P. 161-194.

${ }^{3}$ For the profusion of corporeal gifts in St. Ladislas' vitae as well as for the shaping of the saint's image after that of King Béla III, see especially: Szovák K. The Image of the Ideal Knight in Twelfth-century Hungary. Remarks on the Legend of St Ladislas // Kings and Kingship in Medieval Europe. London, 1993. P. 241-264.

${ }^{4}$ For St. Ladislas' Legend in medieval mural painting, see especially: László Gy. A Szent László-legenda középkori falképei. Budapest, 1993; Gerát I. Willehalm und Ladislaus - Liebe und Kampf in Text und Bild // Ars. 1998. Vol.31, iss. 1-3. P. 49-91; Kerny T. A kerlési ütközet megjelenése és elterjedése az irodalomban majd a képzőművészetben // Folklór és vizuális kultúra. Budapest, 2007. P. 202-257; Năstăsoiu D. Gh. Nouvelles représentations de la Légende de Saint Ladislas à Crăciunel et Chilieni // Revue Roumaine d'Histoire de l’Art. Série Beaux-Arts. 2008. Vol.45. P.3-22; Jékely Zs. Transylvanian Fresco Cycles of Saint Ladislas in a New Light // Hungarian Review. 2014. Vol.5, iss. 2. P.97-109; Jékely Zs. Narrative Structure of the Painted Cycle of a Hungarian Holy Ruler: The Legend of St. Ladislas // Hortus Artium Medievalium. 2015. Vol.21. P.62-74.

${ }^{5}$ For knightly culture in medieval Hungary, see especially: Kurcz Á. A lovagi kultúra Magyarországon a 13-14. században. Budapest, 1988.

${ }^{6}$ Huszár L. Münzkatalog Ungarn von 1000 bis Heute. Munich, 1979. P. 86 (Cat. nos. 514-518). 
providing for its sacred protection ${ }^{7}$. The last decades of the $14^{\text {th }}$ century also witnessed the proliferation of iconic images showing the three sancti reges Hungariae, which were used for both personal-devotional and political-propagandistic purposes ${ }^{8}$. This greatly popular iconography features the Árpádian royal trio composed of: St. Stephen (r. 1000/10011038), the founder of the Christian Kingdom of Hungary, who deserved his sanctity for having ruled as a rex iustus and having converted his people to Christianity; St. Emeric (1000/1007-1031), the former's son, a pious and chaste prince who was educated to become a virtuous Christian ruler but died before succeeding his father to the throne $e^{9}$; and St. Ladislas, ideal ruler and knight, the country's defender against pagan enemies, and athleta patriae. In these images, the three holy kings are depicted together at the three ages of kingship, and are equally invested with royal insignia (crown, scepter, and globus cruciger) and personal attributes, namely: the old and wise St. Stephen - with the scepter and orb; the young and beardless St. Emeric - holding a lily or lily-shaped scepter (an allusion to his chastity); and the mature and armored St. Ladislas - with a battle-axe (a symbol of his knightly bravery).

Previous scholarship has shown that King Sigismund of Luxemburg manifested throughout his reign a constant support for St. Ladislas' cult and that his veneration for the patron saint of the country was genuine and lasting ${ }^{10}$. Since King Sigismund's devotion to St. Ladislas exceeds the short chronological span of the 1401-1403 political crisis, one may assume that the king was not so much concerned with gaining immediate political advantages but was rather interested in the long-term effects of the promotion of the holy king's cult. After all, it was to St. Ladislas' intercession that King Sigismund entrusted the salvation of his soul in 1406, maintaining his wish to be buried next to the sepulcher of the holy king in Nagyvárad even after having become Holy Roman Emperor ${ }^{11}$.

In contrast to King Sigismund and despite having been surrounded by plenty of examples of artistic and pious patronage centered on the cult of Hungarian dynastic saints, which his Neapolitan-Angevin predecessors had disseminated in churches all around

${ }^{7}$ Marosi E. Der heilige Ladislaus als ungarischer Nationalheiliger. Bemerkungen zu seiner Ikonographie im 14.-15. Jh. // Acta Historiae Artium Academiae Scientiarum Hungaricae. 1987-1988. Vol.33, iss. 3-4. P. 244; Marosi E. Der grosse Münzsiegel der Königin Maria von Ungarn: Zum Problem der Serialität Mittelalterlicher Kunstwerke // Acta Historiae Artium Academiae Scientiarum Hungaricae. 1982. Vol.28, iss. 1-2. P.3-22.

8 The most recent and comprehensive work on this iconography is: Năstăsoiu D. Gh. Between Personal Devotion and Political Propaganda: Iconographic Aspects in the Representation of the sancti reges Hungariae in Church Mural Painting (14 $4^{\text {th }}$ Century - Early-16 $6^{\text {th }}$ Century). Budapest, 2018.

9 For the cults of St. Stephen and St. Emeric, see especially: Klaniczay G. Holy Rulers and Blessed Princesses. P. 114-161.

${ }^{10}$ Kerny T. Szent László kultusz a Zsigmond-korban // Müvészet Zsigmond király korában, 13871437. Budapest, 1987. Vol. 1. P.355; Szakács B.Zs. Saints of the Knights - Knights of the Saints: Patterns of Patronage at the Court of Sigismund // Sigismund von Luxemburg: ein Kaiser in Europa. Tagungsband des internationalen historischen und kunsthistorischen Kongresses in Luxemburg, 8.-10. Juni 2005. Mainz, 2006. P.319-320; Năstăsoiu D. Gh. A New sancta et fidelis societas for Saint Sigismund of Burgundy: His Cult and Iconography during the Reign of Sigismund of Luxemburg // The Hungarian Historical Review. Acta Historica Academiae Scientiarum Hungaricae. 2016. Vol. 5, iss. 3. P. 595-598; Năstăsoiu D. Gh. Between Personal Devotion... P. 216-222.

${ }^{11}$ For Sigismund's burial place, see: Kerny T. Begräbnis und Begräbnisstätte von König Sigismund // Sigismundus rex et imperator. Kunst und Kultur zur Zeit Sigismunds von Luxemburg, 1387-1437. Ausstellungskatalog. Mainz, 2006. P. 475-476. 
Naples ${ }^{12}$, King Ladislas seems to have been neglectful of the political value carried by his dynastic belonging to the beata stirps Angevina et Arpadiana ${ }^{13}$. The few surviving works of art associated with his name do not support the claim that King Ladislas exploited - for the purpose of proving the legitimacy of his right to rule the country he unsuccessfully strived for - the political and propagandistic potential offered by the cult and images of his personal patron saint. On the one hand, it is not certain that the frescoes decorating the walls of the chapel situated at the end of the minor nave of the Church of Santa Maria Incoronata in Naples depict episodes taken from St. Ladislas' Life, which the Neapolitan ruler allegedly commissioned around the time of his coronation as King of Hungary in early August $1403^{14}$. It is more likely that these narrative scenes represent in fact a hagiographical cycle dedicated to another holy king, namely, the Angevin St. Louis IX of France, and that they were commissioned by Queen Joanna I of Naples (r. 1343-1382) sometime during the last decade of her reign ${ }^{15}$. On the other hand, King Ladislas' own sepulchral monument in the apse of the Augustinian Church of San Giovanni a Carbonara in Naples was erected some considerable time after the king's death in 1414. Executed only between 1428 and 1431 by a team of artists led by the Pisan sculptor Giovanni di Gante, this impressively-sized mausoleum represents the commission of King Ladislas' sister and successor, Queen Joanna II (r. 1414-1435), who intended through its complex program to celebrate the rulership of both herself and the defunct king as well as to emphasize the

${ }^{12}$ For works of art featuring Hungarian dynastic saints and indicating their veneration by the Neapolitan Angevins, see generally: Prokopp M. Magyar szentek az itáliai trecento festészetben // Magyar szentek tisztelete és ereklyéi. Esztergom, 2000. P.25-35; Kerny T. Középkori Szent László-emlékek nyomában Nápolyban // Ars Hungarica. 1998. Vol.26, iss. 1. P. 52-65; Năstăsoiu D. Gh. Between Personal Devotion... P. 52-61. - For the frescoes of St. Elizabeth Chapel in St. Francis' Lower Basilica in Assisi, see especially: Hoch A.S. Beata stirps, Royal Patronage and the Identification of the Sainted Rulers in the St Elizabeth Chapel at Assisi // Art History. 1992. Vol. 15, iss. 3. P. 279-295; Norman D. Sanctity, Kingship and Succession: Art and Dynastic Politics in the Lower Church at Assisi // Zeitschrift für Kunstgeschichte. 2010. Vol.73, iss. 3. P. 297-334. - For the frescoes of Santa Maria Donna Regina Vecchia in Naples, see especially: Elliott J., Warr C. The Church of Santa Maria Donna Regina: Art, Iconography, and Patronage in the Fourteenth Century Naples. Aldershot, 2004; Fleck C. A. 'Blessed the Eyes That See Those Things You See': The Trecento Choir Frescoes at Santa Maria Donnaregina in Naples // Zeitschrift für Kunstgeschichte. 2004. Vol.67, iss. 2. P.201-224. - For Simone Martini's St. Ladislas panel in Altomonte, see especially: Prokopp M. Simone Martini Szent László képe Altomonte-ben, Szent László és Somogyvár // Szent László és Somogyvár. Tanulmányok a 900 éves somogyvári bencés apátság emlékezetére. Kaposvár, 1992. Vol.1. P. 163-170; Lukács M. Az altomontei Szent László kép története // Acta Historica Hungarica Turiciensia 2005. Vol.7, iss. 1. P. 198-201; Kozlowski S. K. Trecento Panel Painting between the Courts of Naples and Hungary. A Hypothesis for Simone Martini's Saint Ladislaus and a Painting of Christ on the Cross // Convivium. 2019. Vol. 6, iss. 2. P. 78-97.

${ }^{13}$ For sacred lineage, see especially: Vauchez A. 'Beata stirps': sainteté et lignage en Occident aux XIIIe et XIVe siècles // Famille et parenté dans l'Occident médiéval. Rome, 1977. P.397-406; Klaniczay G. Sainteté royale et sainteté dynastique au moyen âge. Traditions, métamorphoses et discontinuités // Les Cahiers du Centre de Recherches Historiques 1989. Iss. 3. P. 69-80; Klaniczay G. Holy Rulers and Blessed Princesses. P. 298-331.

14 The frescoes' identification of subject matter and dating were first proposed by: Bologna F. I pittori alla corte angioina di Napoli 1266-1414, e un riesame dell'arte nell'età fridericiana. Rome, 1969. P. 346-349. - For this interpretative line and its bibliography, see: Vitolo P. 'Miles Christi': san Ladislao d'Ungheria tra mito cavaleresco e culto dinastico. Il ciclo pittorico all'Incoronata di Napoli // La battaglia nel Rinascimento meridionale. Moduli narrativi tra parole e immagini. Rome, 2011. P. 43-56.

${ }_{15}$ Plausibly argued, this hypothesis has been advanced recently by: Ritzerfeld $U$. Johanna I. und die Incoronata in Neapel. Weiblicher Herrschaftsanspruch in der Kirche der 'Regina Dolorosa' // Mitteilungen des Kunsthistorischen Institutes in Florenz. 2017. Vol. 59, iss. 3. P. 283-323. 
ideas of dynastic legitimacy and continuity ${ }^{16}$. Finally, the tomb of Ludovico Aldomoresco - King Ladislas' loyal subject and Captain-General entrusted with the mission of securing the acknowledging of the Neapolitan king's sovereignty over Dalmatia ${ }^{17}$ - should be dismissed as evidence for the transmission of the cult of Hungarian dynastic saints from royal level to that of Neapolitan nobility ${ }^{18}$. Commissioned by his son and executed in 1421 by Antonio Babboccio da Piperno, the tomb was decorated with splendid reliefs depicting Ludovico's and King Ladislas' way to and acceptance into Paradise. Contrary to previous opinion, the sancti reges Hungariae were not included in the iconographic program of this funerary monument ${ }^{19}$.

Whereas King Ladislas seems to have generally ignored the cult of his personal patron saint and holy predecessor, the Hungarian supporters of the Neapolitan ruler proved themselves very attached not only to the cult of St. Ladislas but also to that of St. Stephen. Several of the high prelates involved in the anti-Sigismund coalition chose to be self-represented in their ecclesiastical functions precisely through the images of the two holy kings. The seal of the leader of the anti-royal movement, Archbishop of Esztergom John Kanizsai (1387-1418), features the Enthroned Madonna with Child overlooking the standing figure of St. Adalbert (the patron saint of Esztergom Cathedral) who is flanked by St.Ladislas and St. Stephen (the spiritual patrons of the country ${ }^{20}$ inside a Gothic architectural structure (Fig. 1a). The archbishop kneels humbly below them; his smaller figure is placed in-between two heraldic shields decorated with his coat of arms - an eagle wing carried by a claw ${ }^{21}$. The seal of another participant in the anti-Sigismund movement, Bishop of Győr John Hédervári (1386-1418), displays centrally the standing figure of the

${ }^{16}$ For this tomb, see especially: Abbate F. Il monumento a Ladislao di Durazzo // Atti della giornata di studio Le vie del marmo. Aspetti della produzione e della diffusione di manufatti marmorei tra Quattrocento e Cinquecento. Centro culturale L. Russo. Pietrasanta - 3 ottobre 1992. Florence, 1994. P. 17-22; Lövei P. Anjou-magyar síremlékek és címeres emlékek a Nápolyban // Ars Hungarica 1998. Vol.26, iss. 1. P.37-46. Fig. 13-16; Michalsky T. Memoria und Repräsentation: die Grabmäler des Königshauses Anjou in Italien. Gottingen, 2000. P.159-173; Michalsky T. Tombs and the Ornamentation of Chapels // Artistic Centers of the Italian Renaissance. Naples. Cambridge, 2017. P. 253-254; Pedroni L. Le pseudo-cariatidi del sepolcro di Ladislao di Durazzo. Virtù regali, rappresentazione e ideologia // Iconographica. 2018. Iss. 17. P. 104-116.

${ }^{17}$ For his life and career, see: Del Treppo M. Aldemoresco, Luigi // Dizionario Biografico degli Italiani. II. Albicante-Ammannati. Rome, 1960. P. 83-84.

18 This idea is present in Klaniczay G. Holy Rulers and Blessed Princesses. P. 387.

19 The most complete treatment of this work remains: Bock N. Honor et Gratia. Das Grabmal des Ludovico Aldomoresco als Beispiel familiärer Selbstdarstellung im spätmittelalterlichen Neapel // Marburger Jahrbuch für Kunstwissenschaft 1997. Iss. 24. P. 109-137. - This work, however, is also responsible for the error of introducing the Hungarian holy rulers into the picture, both literally and metaphorically. Based on a wrong identification of one of the interceding saints with St. Emeric instead of the $11^{\text {th }}$-century St. Amatus of Nusco (called sant ayme in the accompanying Old French inscription), the scholar unfoundedly described the defunct admiral and king as enjoying the grace of the beata stirps (Ibid. P. 122). This concept is completely missing from the tomb's iconography, as missing is any of Hungary's holy kings for that matter. For St. Amatus' correct identification, see: Modena S. 'Tituli', iscrizioni e motti: il francese esposto in Italia fra XIV e XV secolo // Francigena. 2016. Iss. 2. P.176.

20 Arch. Saec. Acta Rad. R. No. 8, Archiepiscopal Archives, Esztergom, impressed between 1391 and 1394, casting, $9.0 \times 5.3 \mathrm{~cm}$ (Bodor I. A középkori Magyarország föpapi pecsétjei a Magyar Tudományos Akadémia Művészettörténeti Kutató Csoportjának pecsétmásolat-gyújteménye alapján. Budapest, 1984. P. 54. Pl. XII).

${ }^{21}$ For the coat of arms of Osl kindred which the Kanizsais belonged to, see: Körmendi T. Az Osl nemzetség címerváltozásai a középkorban // Turul. 2010. Vol. 83, iss. 1. P.3-24. 

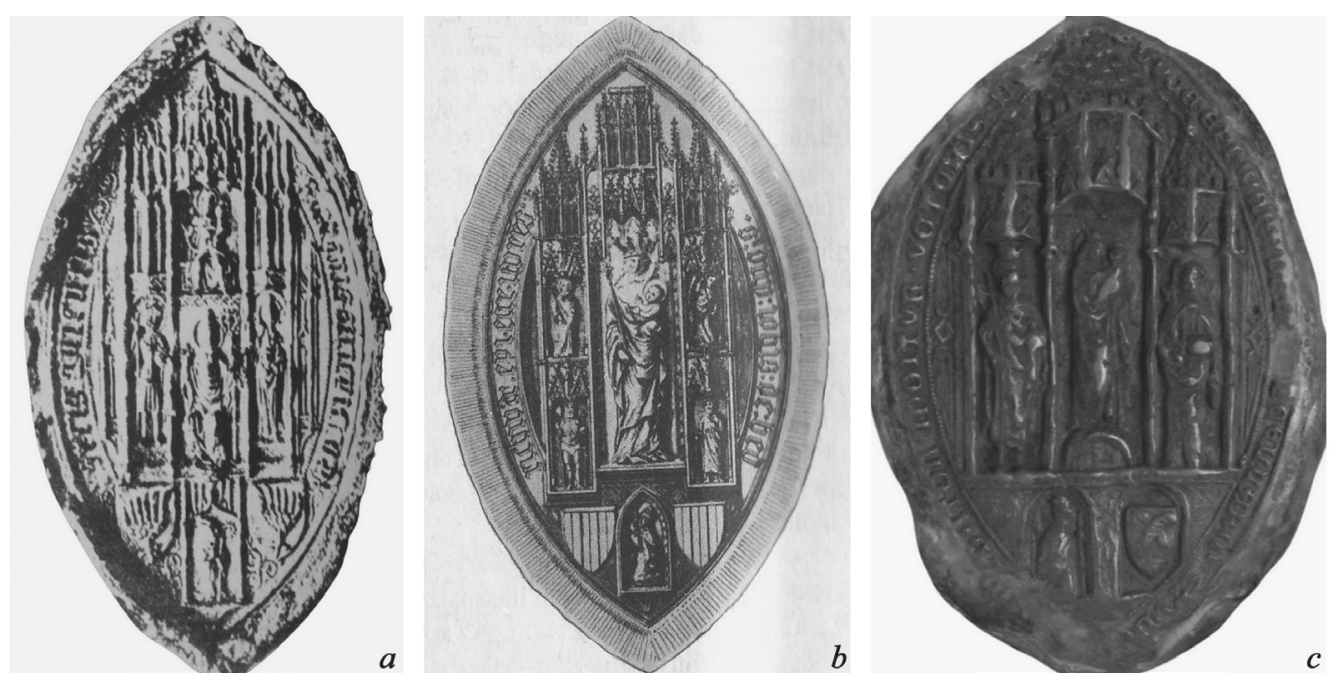

Fig 1. Seals of three ecclesiastical participants in the anti-royal conspiracy: $a$ - Impression of the seal of Archbishop of Esztergom John Kanizsai, 1391-1394, casting, $9.0 \times 5.3 \mathrm{~cm}$ (Archiepiscopal Archives, Esztergom) [Bodor I., 1984]; $b$ - Drawing of the seal of Bishop of Győr John Hédervári, 1397, $8.5 \times 4.6 \mathrm{~cm}$ (Hungarian National Archives, Budapest) [Feiszt Gy. Rövid magyar címertan és pecséttan. Budapest, 1986]; c - Impression of the seal of Bishop of Nagyvárad Lucas Szántai, 1398, red wax, $7.6 \times 4.7 \mathrm{~cm}$ (Hungarian National Archives, Budapest). URL: https://archives.hungaricana. $\mathrm{hu} / \mathrm{hu} / \mathrm{charters} / 87594 /$

cathedral's patron, the Child-holding Holy Virgin ${ }^{22}$ (Fig. 1b). She is flanked by four smaller figures inserted in Gothic canopied niches: St. Peter and Archangel Michael (upper register) and St. Ladislas and St. Stephen (lower register). Likewise, the kneeling bishop is depicted in a devotional pose at the seal's bottom and in-between two shields featuring his coat of arms - the Hungarian (red-and-white) stripes arranged, however, vertically. One can add to these examples the seal of Bishop of Nagyvárad Lucas Szántai (1387-1406), with the standing figures of St. Ladislas, Holy Virgin with Child, and St. Peter ${ }^{23}$ in a simplified architectural structure (Fig. 1c). In this case, however, the choice for depicting the Holy Virgin centrally with St. Ladislas on her right seems only natural as the two were the actual patron saints of the Cathedral of Nagyvárad. Thus the iconography of these seals combines - in their self-representational function - the devotional and political aspirations of the prelates who actively participated in the conspiracy against King Sigismund. One may assume that their seals have been applied to a great number of charters during the three bishops' episcopacies, and that they had circulated both inside and outside the respective dioceses, communicating their highly-symbolic iconography to a very wide audience $^{24}$.

22 DL 87647, Hungarian National Archives, Budapest, 1397, red wax, $8.5 \times 4.6 \mathrm{~cm}$ (Bodor I. A középkori Magyarország föpapi pecsétjei... P.53-54. Pl. XIII).

${ }^{23}$ DL 8313, Hungarian National Archives, Budapest, 1398, red wax, $7.6 \times 4.7 \mathrm{~cm}$ (Bodor I. A középkori Magyarország föpapi pecsétjei... P.56. Pl. XIV; Bunyitay V. A váradi püspökség története alapításától a jelenkorig. Első kötet. A váradi püspökok a püspökség alapításától 1566. évig. Nagyvárad, 1883. P.223-224).

${ }^{24}$ For the usage of seals and their ideological content in the medieval West, see especially: BedosRezak B. M.: 1) When Ego Was Imago. Signs of Identity in the Middle Ages. Leiden, 2011;2) Seals. Making 

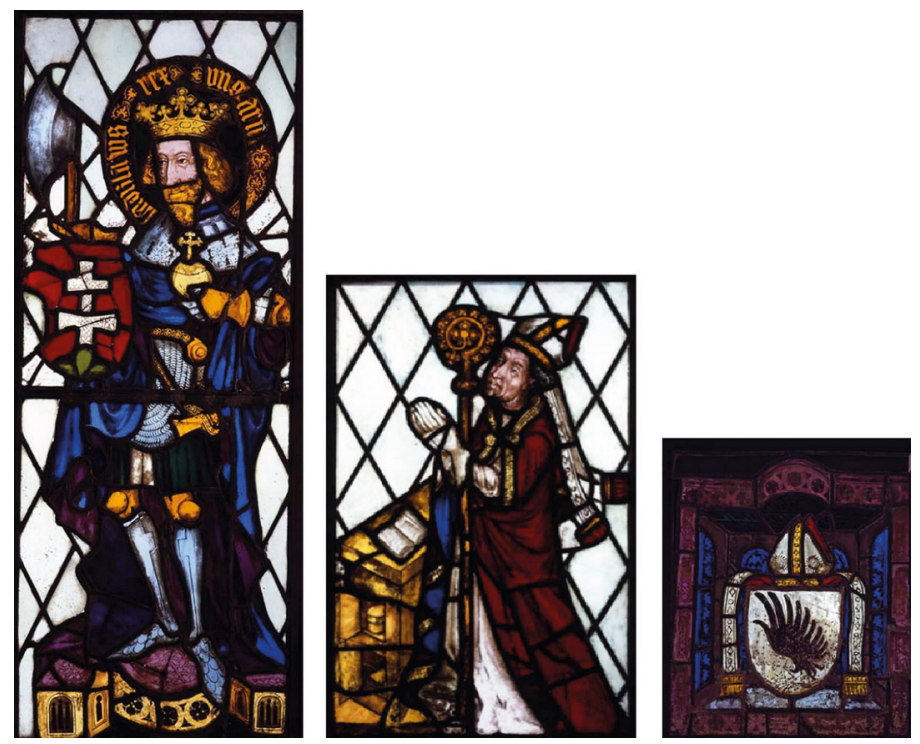

Fig. 2. St. Ladislas, Archbishop of Esztergom John Kanizsai, and the Kanizsai's coat of arms, 1416, stained glass, $123 \times 48 \mathrm{~cm}, 74.5 \times$ $48 \mathrm{~cm}$, and $45 \times 45 \mathrm{~cm}$ (Church of the Former Carthusian Monastery St. Margaretenthal, Basel) [Szentmártoni Szábó G., 2011]

Archbishop John Kanizsais' personal devotion towards St. Ladislas did not cease even after his anti-Sigismund conspiracy failed, and he reconciled with the king playing again subsequently an important role in the kingdom's political and diplomatic affairs. This is illustrated by one of the archbishop's artistic and pious commissions happening most likely during the summer of 1416, when John Kanizsai was attested in Basel ${ }^{25}$. While being there, the archbishop ordered for the church of the former Carthusian monastery a series of stained-glass windows to decorate the area of the church's spiral stairs ${ }^{26}$ (Fig. 2). Varying in size, the three stained glasses display the archbishop's coat of arms and his image as a donor praying to St. Ladislas ${ }^{27}$. Having his halo inscribed as Ladislaus rex ungarie, the crowned holy knight holds a globus cruciger, his usual battle-axe attribute, and a red

and Marking Connections across the Medieval World. Leeds, 2018; Schofield Ph. R. Seals and Their Context in the Middle Ages. Oxford, 2015; Whatley L. A Companion to Seals in the Middle Ages. Leiden, 2019.

${ }^{25}$ Kondor M. A királyi kúria bíróságaitól a kancelláriáig. A központi kormányzat és adminisztráció Zsigmond-kori történetéhez // Századok. 2008. Vol. 142, iss. 2. P. 436.

${ }^{26}$ Kept for a long time in the Historisches Museum in Basel, the windows were returned to their initial owner but were relocated at the basis of the choir's central window. The archbishop's name is inscribed in the monastery's book of benefactors (Ms 1b Wohltäterbuch der Karthause, Basler Staatsarchiv in Basel, fol. 249): "III. reverendissimus pater dominus Johannes Archiepiscopus Strigoniensis de Ungaria dedit XX florenos pro fenestra vitrea prope cocleam.” - apud Szentmártoni Szábó G. Kanizsai János esztergomi érsek korabeli portréja és címere Bázelban // Turul. 2011. Vol.81, iss. 4. P. 137-139.

$27123 \times 48 \mathrm{~cm}, 74.5 \times 48 \mathrm{~cm}$, and $45 \times 45 \mathrm{~cm}$, stained glass (Burckhardt R. F. Die gotischen Glasgemälde der ehemaligen Karthäuserkirche, jetzigen Waisenhauskirche zu Basel // Jahresberichte und Rechnungen des Vereins für das Historische Museum und für Erhaltung baslerischer Altertümer und der Kommission zum historischen Museum, Jahr 1915. Basel, 1916. P. 18-27; Verzár F. Régi magyar vonatkozások Bázelben // Debreceni Szemle. 1931. Iss. 5. P.310-314; Baer C. H. Die Kartause in Klein-Basel // Die Kunstdenkmäler des Kantons Basel-Stadt. Basel, 1941. Vol. 3. P. 449-594). 
shield decorated with the Árpádian double cross. This heraldic detail reinforces the idea that St. Ladislas was indeed revered as the patron saint of the realm.

It is interesting to examine whether Palatine Detre (Detricus) Bebek, as one of the heads of the anti-Sigismund coalition, or his son, Prior of Vrana Emeric Bebek, as an active participant in the rebellion, followed the model set up by these ecclesiastical figures and employed in a political and propagandistic manner the images of Hungary's holy kings. Five of the many churches where representations of the three sancti reges Hungariae (Fig. 3) can be seen, were located at the turn of the $14^{\text {th }}$ and $15^{\text {th }}$ centuries on settlements that belonged to the estate of the so-called Pelsöci branch of the Bebek family. Four of them were found in Gömör County (present-day Slovakia): All Saints Church in Krásnohorské Podhradie (Hung. Krasznahorkaváralja); St. Ladislas Church in Kameňany (Hung. Kövi); Church of the Holy Virgin and St. George in Plešivec (Hung. Pelsöc); and Holy Trinity Church in Rákoš (Hung. Gömörrákos) ${ }^{28}$. The fifth one - St. Andrew Church in Tornaszentandrás (present-day Hungary) was located in the neighboring Torna County ${ }^{29}$. A detailed discussion of these murals' iconography, style, and state of preservation is not possible here, but it should be noted that all five were executed roughly during the same period that coincided with the troubled time of political crisis: the late $14^{\text {th }}$ century for Krásnohorské Podhradie; the 1390s for Kameňany, Rákoš, and Tornaszentandrás; and around 1400 for Plešivec ${ }^{30}$. Additionally, the iconographic program of the nave's northern wall in Holy Trinity Church in Rákoš included the representation of another popular theme focusing on St. Ladislas' chivalric and chivalrous exploits, namely, the so-called Legend of St. Ladislas. A similar combination can be also found in the church in Remetea (present-day Romania, Hung. Magyarremete/Biharremete), whose sanctuary and the nave's northern wall were likewise decorated around 1400 with the image of the sancti reges Hungariae and St. Ladislas' Legend, respectively ${ }^{31}$. Although the iconic and narrative representations are rarely in a direct conceptual relationship ${ }^{32}$, the presence of both types of images in the general iconographic program of a single church is, nonetheless, indicative of the great veneration of St. Ladislas during the $14^{\text {th }}$ and $15^{\text {th }}$ centuries. In Remetea, the visual emphasis on the cult of Hungarian holy rulers was motivated not only by the

${ }^{28}$ For the settlements' history and their ownership by the Pelsőci Bebeks, see: Borovszky S. Magyarország vármegyéi és városai (Magyarország monografiája). A Magyar Korona Országai történetének, földrajzi, képzőművészeti, néprajzi, hadügyi és természeti viszonyainak, közművelödési és közgazdasági állapotának encziklopédiája. Gömör-Kishont vármegye. Budapest, 1903. P.60-61 (Kameňany), 61-67 (Krásnohorské Podhradie), 77-78 (Plešivec), 84-85 (Rákoš). See also: Tihányiová M. Dejiny Kamenian s dôrazom na ev. a. v. kostol // Najnovšie poznatky z výskumov stredovekých na Gotickej ceste - Zborník Gotiská cesta. 2016. Iss. 2. P. 37-50.

${ }^{29}$ In 1388, an administrator of the future Palatine Detre Bebek already resided in the village, a sign that the settlement became part of the Pelsőci Bebeks' estate before that year. - Valter I. A tornaszentandrási r. k. templom kutatása // A Herman Ottó Múzeum Évkönyve. 1980. Iss. 19. P.103. - This representation shows only the standing figures of Sts Ladislas and Stephen facing each other on the triumphal arch's pillars; for this particular iconographic type, see: Năstăsoiu D. Gh. Between Personal Devotion... P. 168-193.

30 Extensive discussion of the murals' dating is found in: Năstăsoiu D. Gh. Between Personal Devotion... P. 192-193 (Tornaszentandrás), 366-368 (Krásnohorské Podhradie), 379-381 (Plešivec), 390394 (Rákoš). - This work includes also the monuments' exhaustive bibliography up to 2018. Currently, the sanctuary in Kameňany is partially whitewashed and the murals' uncovering and restoration in not completed yet. The image of the sancti reges Hungariae is only partly visible (Ibid. P. 108-109, 111-114, 116-117, 120-122, 189, 193, 288, 311).

31 Năstăsoiu D. Gh. Between Personal Devotion... P. 395-404.

32 Ibid. P. 120. 


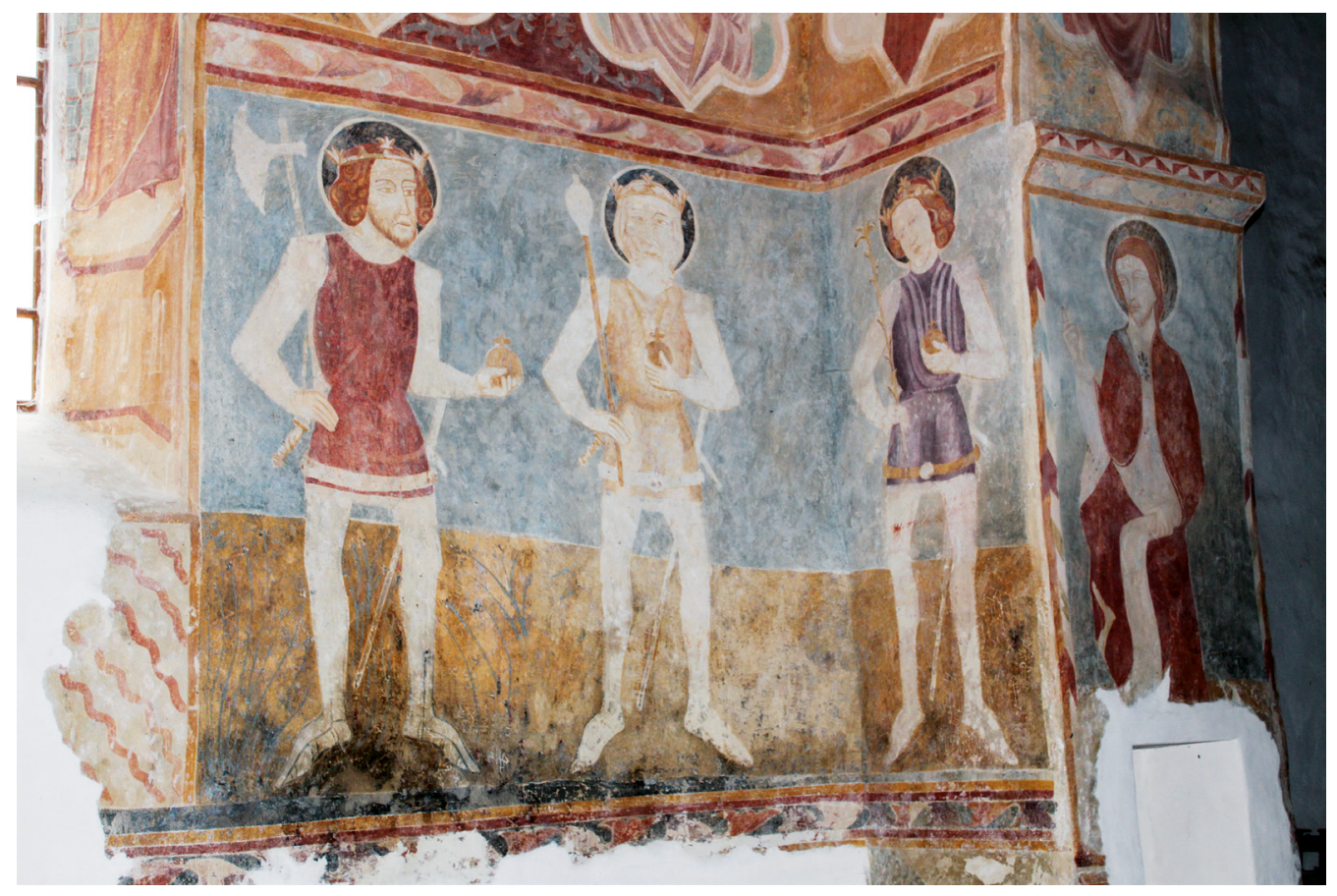

Fig. 3. Sts Ladislas, Stephen, and Emeric (sancti reges Hungariae), 1390s, fresco, southern side of the sanctuary (Roman Catholic Church of the Holy Trinity, Rákoš). Photo: D. Gh. Năstăsoiu

settlement's location in the proximity of St. Ladislas' cult center in Nagyvárad, but also by the settlement's ownership. Starting with 1318 and until around the mid- $15^{\text {th }}$ century, the settlement in Remetea was mentioned in written sources as part of the estate of the Bishops of Nagyvárad ${ }^{33}$. They were the main promoters of the holy king's cult, whereas Bishop Lukas Szántai himself was an active participant in the anti-Sigismund rebellion.

Throughout the second half of the $14^{\text {th }}$ century, some of the members of the Bebek family held high dignities and offices, which allowed them to play an important political role in the kingdom as well as to cumulate an impressive wealth ${ }^{34}$. Detre Bebek himself (mid-14 ${ }^{\text {th }}$ century - after 1404), started his career as the queen's steward (1379); then he became royal standard-bearer and magister curiae regiae (1388), Ban of Croatia, Dalmatia, and Slavonia (1389-1392, 1394-1397), Ban of Szöreny and Temes (1392-1393), and finally rose to the highest office in the kingdom, that of Palatine of Hungary (1397-1402). In 1396, the Pelsőci Bebeks alone owned seven castles $^{35}$, four of them being situated in Gömör County, in the proximity of their estates where the churches in Kameňany, Rákoš,

${ }^{33}$ Szakács B. Zs. Saints of the Knights... P. 329; Lángi J., Mihály F. Erdélyi falképek és festett faberendezések. Budapest, 2004. Vol.2. P.71; Năstăsoiu D. Gh. Between Personal Devotion... P. 120, 304-306, 395-404.

34 Nagy I. Magyarország családai czimerekkel és nemzékrendi táblákkal. Vol. 1. Pest, 1857. P. 256-263; Borovszky S. Gömör-Kishont vármegye. P.633; Engel P. Magyarország világi archontológiája 1301-1457. Vol.2. Budapest, 1996. P. 103-104; Skalská M. Rod Bubekovcov z Plešivca do začiatku 15. storočia // Historický zborník. 2010. Vol.20, iss. 2. P.19-45; Tihányiová M. A pelsőci Bebekek. Egy nemesi család felemelkedése és bukása. Rozsnyó, 2019.

35 Engel P. The Realm of St Stephen. A History of Medieval Hungary, 895-1526. London, 2001. P. 200. 
Plešivec, and Krásnohorské Podhradie were also located. Their main residence was in the town of Plešivec, an important link between the commercial roads of Buda and Košice to Poland. It was in this town that their main family church was founded, which - during the late- $14^{\text {th }}$ century - was decorated (both inside and outside) with exquisite murals bearing the imprint of the so-called "Italian Trecento style" 36 . As attested by the formal qualities of the remaining frescoes, the artistic patronage of the Pelsöci Bebeks extended during the same period also to other churches situated on their properties, including Kameňany, Rákoš, Tornaszentandrás, and Krásnohorské Podhradie. Judging by their naming practices throughout the $14^{\text {th }}$ and first half of the $15^{\text {th }}$ century, it is not surprising that the depiction of the sancti reges Hungariae was found in so many of their churches as the members of the Bebek family were often named Ladislas (6 times), Stephen and Emeric (each 3 times $)^{37}$. The Bebeks' close, personal link with their spiritual patrons is clearly expressed in the murals of the church in Rákošs8 (Fig. 3). Here, Hungary's holy kings are depicted on the lower register of the sanctuary's southern wall, that is, in the immediate vicinity of the place where the church's patrons usually attended the religious service $^{39}$. However, besides the Bebeks' personal motivation in venerating and depicting the Hungarian royal saints in their churches, there was a political and ideological reasoning also. Placed on the outer wall of their main family church (on the sanctuary's southern wall), the image of the three sancti reges Hungariae in Plešivec obviously did not fulfill an immediate liturgical function ${ }^{40}$ (Fig. 4). Even though it is currently poorly and partially preserved, this image enjoyed a high degree of visibility, accessible to everybody who happened to be in the town square, and it was probably intended to satisfy its commissioners' need for self-representation ${ }^{41}$ (Fig. 5). Judging by their naming practices and personal-devotional ties with the three holy kings, it is possible to assume that the Pelsöci Bebeks tried to emulate the saintly and political virtues the sancti reges Hungariae stood for.

${ }^{36}$ For stylistic considerations on the murals of Gömör County in the late-medieval period, see: Prokopp M.: 1) Italian Trecento Influence on Murals of East Central Europe, Particularly Hungary. Budapest, 1983; 2) Gömöri falképek a XIV. században // Müvészettörténeti Értesítő. 1969. Vol. 18, iss. 2. P. 128 148; 3) Középkori freskók Gömörben. Somorja, 2002. P.21-26, 28-30; Togner M. Stredoveká nástenná malba v Gemeri. Bratislava, 1989; Plekanec V., Haviar T. Gotický Gemer a Malohont. Italianizmy v stredovekej nástennej malbe. Gothic Gemer and Malohont. Italianizing in Medieval Wall Painting. Martin, 2010. 104.

37 Nagy I. Magyarország családai... P. 256-263; Engel P. Magyarország világi archontológiája... P. 103-

38 For these murals, see especially: Dvořáková V., Krása J., Stejskal K. Stredoveká nástenná mal'ba na Slovensku. Prague-Bratislava, 1978. P. 135-136; Prokopp M.: 1) Italian Trecento Influence... P.79-80, 174, 176; 2) Középkori freskók Gömörben. P.21-26; Kušnierová E. Stredoveká nástenná malba z Rákoša // Pamiatky a múzeá 1995 . Vol.2, iss. 44. P.1-17.

39 Năstăsoiu D. Gh. Between Personal Devotion... P. 122. - An indication of St. Ladislas' special veneration by the Bebeks might have been also reflected in the dedication of the church in Kameňany to this holy king. Even though there are reasons to believe that this was the church's medieval dedication, the titulus appears first in written sources only at the end of the $17^{\text {th }}$ century (Tihányiová M. Dejiny Kamenian... P. 45).

${ }^{40}$ For these murals, see especially: Dvořáková V., Krása, J., Stejskal K. Stredoveká nástenná malba na Slovensku. P. 48; Prokopp M.: 1) Italian Trecento Influence... P.78; 2) Középkori freskók Gömörben. P. 28-30; Buran D. Gotika. Dejiny slovenského výtvarného umenia. Bratislava, 2003. P. 327-328; Togner M. Stredoveká nástenná malba v Gemeri. P.93, 178-179; Szakálos É. A pelsőci templom 14. századi falképei // Ars Hungarica 2013. Vol.39, iss. 2. P.212-219.

${ }^{41}$ Năstăsoiu D. Gh. Between Personal Devotion... P. 125-126. - For the holy kings' representation on exterior walls of medieval churches, see also: Kerny T. Magyar szent királyok középkori kompozíciói a templomok külső falain // Omnis creatura significans. Tanulmányok Prokopp Mária 70. születésnapjára. Essays in Honor of Mária Prokopp. Budapest, 2009 P. 81-88. 


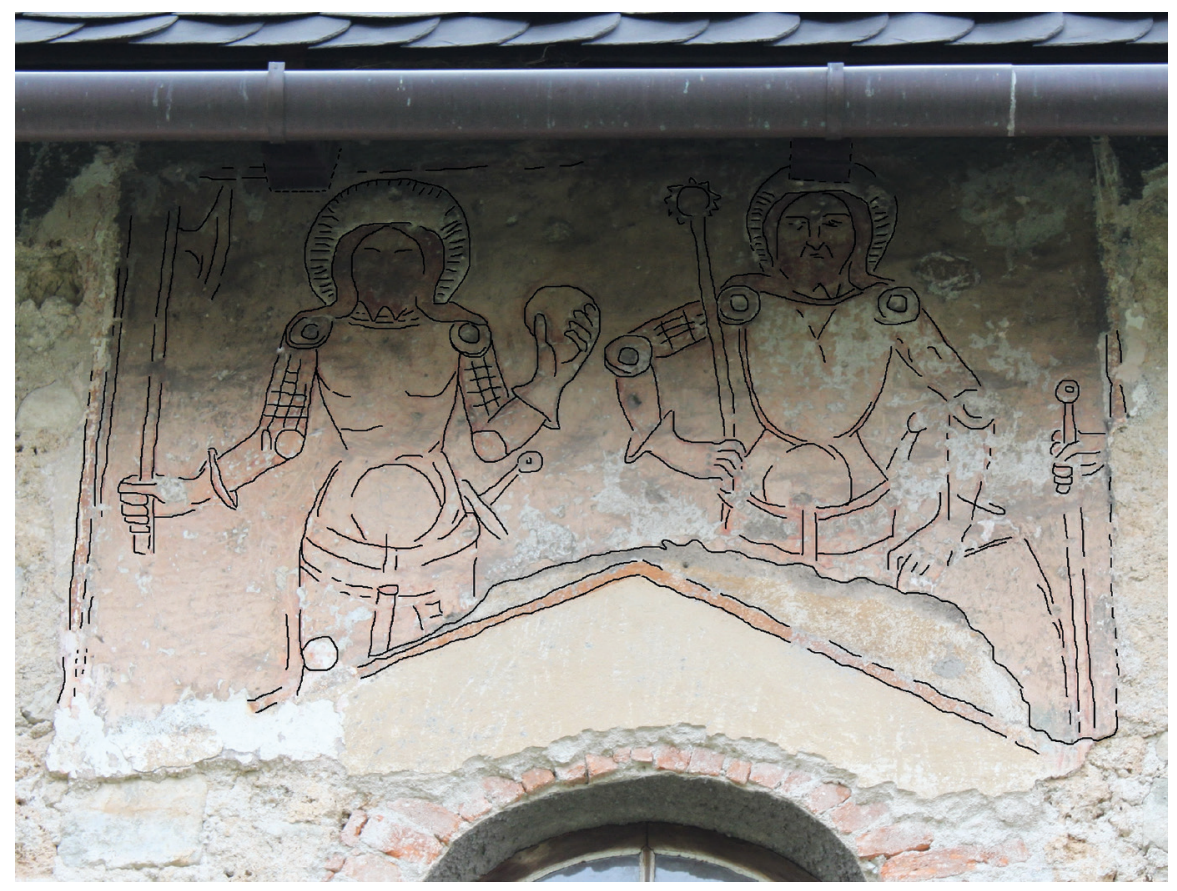

Fig. 4. St. Ladislas, St. Stephen (and St. Emeric), c. 1400, drawing on the holy kings' representation, fresco, southern exterior wall of the sanctuary (Calvinist (formerly Catholic) Church (of the Holy Virgin and St. George), Plešivec). Photo \& Drawing: D. Gh. Năstăsoiu

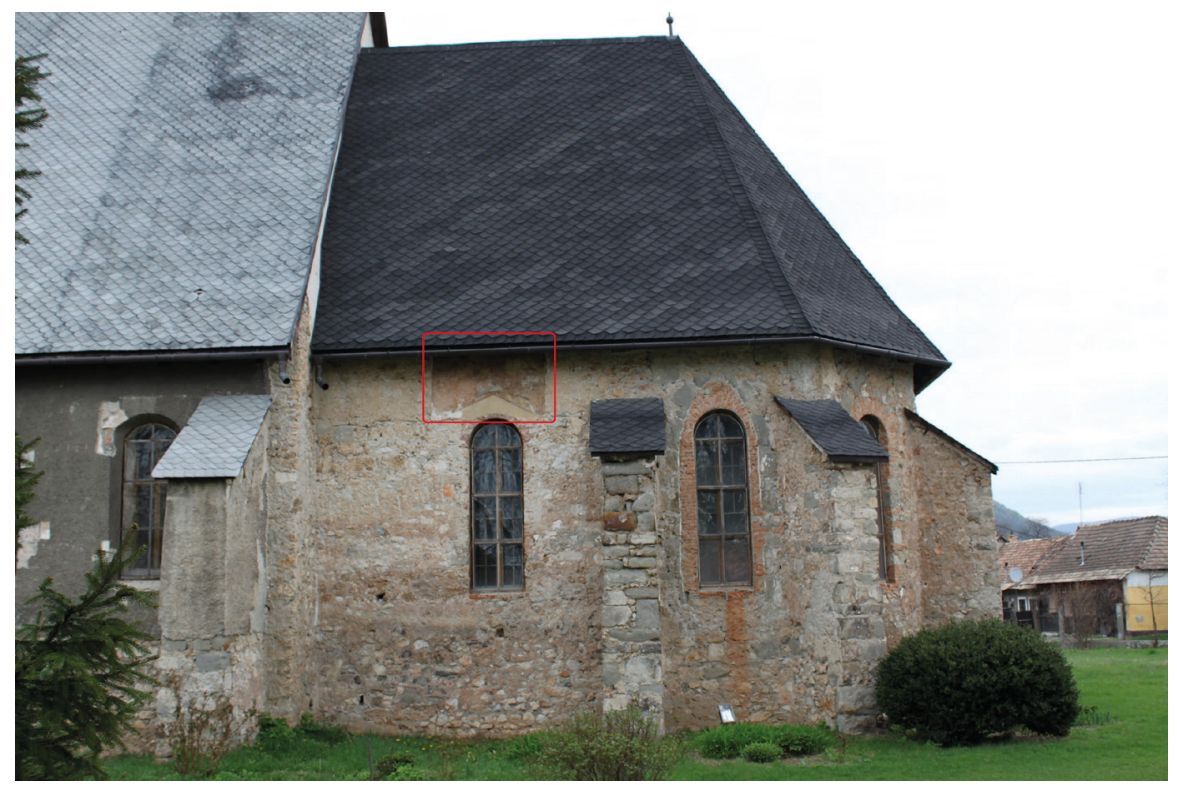

Fig. 5. View of the southern wall of the sanctuary with marking of the location of the holy kings' scene, c. 1400 (Calvinist (formerly Catholic) Church (of the Holy Virgin and St. George), Plešivec). Photo \& Drawing: D. Gh. Năstăsoiu 
The Bebeks' self-identification with and self-representation through other important symbols of the realm was manifest also, after the middle of the $14^{\text {th }}$ century, in the repeated depiction of the two-barred cross on their coat of arms. Still kept inside the remarkable Gothic chapel that the Pelsőci Bebeks added around 1400 to the northern side of their family church in Plešivec ${ }^{42}$, the tombstone of Ladislas Bebek displays a shield decorated with the double cross surmounted by a tuft of feathers ${ }^{43}$ (Fig. 6). There is a crest on top of its helmet with a torse featuring the heraldic symbol of the Ákos kindred, namely, a crowned female head surrounded by two fish coming out of her mouth. A variant of this coat of arms also appears on Detre Bebek's own seal as Palatine of Hungary, the prominent Melusine-like coat of arms of the Ákos kindred being flanked this time by two smaller shields, each of them decorated with the double cross symbolizing the realm ${ }^{44}$ (Fig. 7). The incorporation of the country's symbol into their heraldry signified that the Bebeks identified themselves strongly with the realm, whose proud and wealthy noblemen they were. By appropriating this heraldic element, the Bebeks vainly asserted their self-importance and expressed the conviction that their family was meant to play a significant and decisive part on their country's political stage ${ }^{45}$. The exterior wall paintings of the church in Plešivec are greatly damaged now, so one can no longer know whether the Bebeks' coat of arms (and of their country for that matter) featured or not on the shields of the sancti reges Hungariae, as it happened in many other instances ${ }^{46}$ (Figs. 4, 5). However, it is probable that having been deeply involved in the political crisis of the early $15^{\text {th }}$ century, when the powerful symbol of St. Ladislas was repeatedly employed in their favor by some of the prominent members of the anti-Sigismund coalition, Detre (and Emeric) Bebek also attempted to convey political and ideological messages through

42 Szakács B. Zs. Saints of the Knights... P. 323.

$43231 \times 117$ cm, red marble, 1401 (Csoma J. Magyar sírkövek. I. Bebek György sírköve 1371. II. Bebek László sírköve 1401 // Turul. 1888. Iss. 6. P. 159-164; Engel P., Lövei P., Várga L. Grabplatten von ungarischen Magnaten aus dem Zeitalter der Anjou-Könige und Sigismunds von Luxemburg // Acta Historiae Artium Academiae Scientiarum Hungaricae. 1984. Iss. 30. P. 45; Tihányiová M. A Pelsőci Bebek család temetkezési helyei és síremlékei // Történelem és Muzeológia — Internetes Folyóirat Miskolcon. 2018-2019. Vol.5, iss. 1-2. P. 130-143). - Magister tavarnicorum until 1393, Ladislas Bebek ceased to play an active role on the kingdom's political stage after this date. He remained active until 1403 and was mentioned as deceased only in 1404. However, his tomb slab was executed earlier, as indicated by the 1401 date carved on it.

44 DL 5522, Hungarian National Archives, Budapest, 1399, wax, diameter $5.5 \mathrm{~cm}$ (Tihányiová M. A Pelsőci Bebek család temetkezési helyei és síremlékei. P.136, fig. 2.2). For this heraldic variation, see also: Nagy I. Magyarország családai... P. 262-263.

45 Năstăsoiu D. Gh. Between Personal Devotion... P. 127.

46 For such examples, see: Ibid. P. 129-155. 


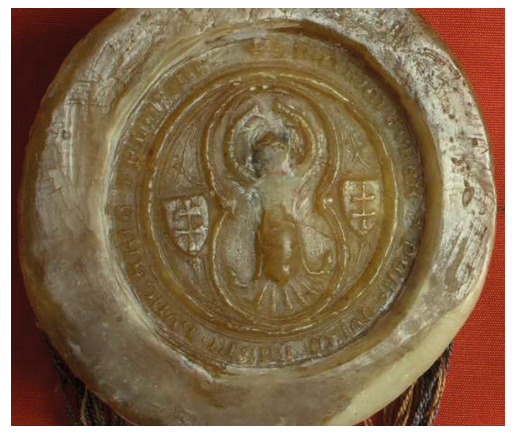

Fig. 7. Impression of the seal of the Palatine of Hungary Detre Bebek, 1399, wax, diameter $5.5 \mathrm{~cm}$ (Hungarian National Archives). URL: https://archives.hungaricana.hu/hu/ charters/59395/ cults and images of the patron saints of the country blended harmoniously the commissioners' personal piety and political ambition. By expressing their devotion towards the patron saints of the country and by commissioning works of art with their image, the two leaders of the anti-royal movement hoped to attract the holy kings' divine support in favor of their political cause. Moreover, by appropriating the realm's heraldry and by incorporating it into their personal coat of arms, the Bebeks asserted their self-importance and identified themselves strongly with the realm and its political fate. This wide range of visual propaganda tools employed by the two leaders of the anti-Sigismund coalition was meant to prove the legitimacy of their political cause. As shown previously, the propagandistic usage of these visual tools was reinforced by the insertion of other heraldic, political, and spiritual symbols into elaborated rituals and symbolic actions (e.g., oath-swearing and coronations). In the context of the early- $15^{\text {th }}$ century political crisis, the appropriation of the ideal figures of St. Ladislas and the other two sancti reges Hungariae became the driving force behind the Hungarian noblemen's political cause. The involvement of the holy kings in elaborated rituals and symbolic actions was meant to activate the link between secular and religious spheres, the performers hoping to attract the divine approval in this way. However, positive outcome for symbolic and ritual actions was not always granted by divinity, as illustrated by the failure of the anti-royal coalition to reach their goal.

\section{References}

Abbate F. Il monumento a Ladislao di Durazzo. Atti della giornata di studio Le vie del marmo. Aspetti della produzione e della diffusione di manufatti marmorei tra Quattrocento e Cinquecento. Centro culturale L. Russo. Pietrasanta - 3 ottobre 1992. Florence, Giunti, 1994, 88 p.

Baer C.H. Die Kartause in Klein-Basel. Die Kunstdenkmäler des Kantons Basel-Stadt. Basel, 1941, vol.3, pp. 449-594.

Bedos-Rezak B. M. Seals. Making and Marking Connections across the Medieval World. Leeds, Amsterdam University Press and ARC Humanities Press, 2018, 256 p.

Bedos-Rezak B. M. When Ego Was Imago. Signs of Identity in the Middle Ages. Leiden, Brill, 2011, 295 p.

Bock N. Honor et Gratia. Das Grabmal des Ludovico Aldomoresco als Beispiel familiärer Selbstdarstellung im spätmittelalterlichen Neapel. Marburger Jahrbuch für Kunstwissenschaft, 1997, iss. 24, pp. 109-137. 
Bodor I. A középkori Magyarország fópapi pecsétjei a Magyar Tudományos Akadémia Müvészettörténeti Kutató Csoportjának pecsétmásolat-gyüjteménye alapján. Budapest, MTA Müvészettörténeti Csoport, 1984, 75 p., XXVIII pl.

Bologna F. I pittori alla corte angioina di Napoli 1266-1414, e un riesame dell'arte nell'età fridericiana. Rome, Ugo Bozzi Editore, 1969, 398 p.

Borovszky S. Magyarország vármegyéi és városai (Magyarország monografiája). A Magyar Korona Országai történetének, földrajzi, képzömüvészeti, néprajzi, hadügyi és természeti viszonyainak, közmüvelödési és közgazdasági állapotának encziklopédiája. Gömör-Kishont vármegye. Budapest, Apollo Irodalmi Társaság, 1903, 677 p.

Buran D. Gotika. Dejiny slovenského výtvarného umenia. Bratislava, Slovenská Národná Galéria and Slovart, 2003, 879 p.

Burckhardt R.F. Die gotischen Glasgemälde der ehemaligen Karthäuserkirche, jetzigen Waisenhauskirche $\mathrm{zu}$ Basel. Jahresberichte und Rechnungen des Vereins für das Historische Museum und für Erhaltung baslerischer Altertümer und der Kommission zum historischen Museum, Jahr 1915. Basel, Basler Druckund Verlags-Anstalt, 1916, pp. 18-27.

Csoma J. Magyar sírkövek. I. Bebek György sírköve 1371. II. Bebek László sírköve 1401. Turul, 1888, iss.6, pp. $159-164$.

Del Treppo M.Aldemoresco, Luigi. Dizionario Biografico degli Italiani. II. Albicante-Ammannati. Rome, Istituto della Enciclopedia Italiana, 1960, pp. 83-84.

Dvořáková V., Krása J., Stejskal K. Stredoveká nástenná malba na Slovensku. Prague-Bratislava, OdeonTatran, 1978, $407 \mathrm{p}$.

Elliott J., Warr C. The Church of Santa Maria Donna Regina: Art, Iconography, and Patronage in the Fourteenth Century Naples. Aldershot, Ashgate, 2004, 234 p.

Engel P. Magyarország világi archontológiája 1301-1457, vol.2. Budapest, MTA Történettudományi Intézete, 1996, 266 p.

Engel P. The Realm of St Stephen. A History of Medieval Hungary, 895-1526. London, I. B. Tauris, 2001, 452 p.

Engel P., Lővei P., Várga L. Grabplatten von ungarischen Magnaten aus dem Zeitalter der Anjou-Könige und Sigismunds von Luxemburg. Acta Historiae Artium Academiae Scientiarum Hungaricae, 1984, iss. 30, pp.33-63.

Feiszt Gy. Rövid magyar címertan és pecséttan. Budapest, Tankönyvkiadó, 1986, 100 p.

Fleck C. A. 'Blessed the Eyes That See Those Things You See': The Trecento Choir Frescoes at Santa Maria Donnaregina in Naples. Zeitschrift für Kunstgeschichte, 2004, vol. 67, iss. 2, pp. 201-224.

Gerát I. Willehalm und Ladislaus — Liebe und Kampf in Text und Bild. Ars, 1998, vol.31, iss. 1-3, pp. 49-91.

Hoch A.S. Beata stirps, Royal Patronage and the Identification of the Sainted Rulers in the St Elizabeth Chapel at Assisi. Art History, 1992, vol. 15, iss. 3, pp. 279-295.

Huszár L. Münzkatalog Ungarn von 1000 bis Heute. Munich, Battenberg, 1979, 363 p.

Jékely Zs. Narrative Structure of the Painted Cycle of a Hungarian Holy Ruler: The Legend of St. Ladislas. Hortus Artium Medievalium, 2015, vol.21, pp. 62-74.

Jékely Zs. Transylvanian Fresco Cycles of Saint Ladislas in a New Light. Hungarian Review, 2014, vol. 5, iss. 2, pp. 97-109.

Kerny T. A kerlési ütközet megjelenése és elterjedése az irodalomban majd a képzőművészetben. Folklór és vizuális kultúra. Budapest, Akadémiai Kiadó, 2007, pp.202-257.

Kerny T. Begräbnis und Begräbnisstätte von König Sigismund. Sigismundus rex et imperator. Kunst und Kultur zur Zeit Sigismunds von Luxemburg, 1387-1437. Ausstellungskatalog. Mainz, Philipp von Zabern, 2006, pp.475-476.

Kerny T. Középkori Szent László-emlékek nyomában Nápolyban. Ars Hungarica, 1998, vol. 26, iss. 1, pp. 5265.

Kerny T. Magyar szent királyok középkori kompozíciói a templomok külső falain. Omnis creatura significans. Tanulmányok Prokopp Mária 70. születésnapjára. Essays in Honor of Mária Prokopp. Budapest, CentrArt Egyesület, 2009, pp. 81-88.

Kerny T. Szent László kultusz a Zsigmond-korban. Müvészet Zsigmond király korában, 1387-1437, vol.1. Budapest, Budapesti Történeti Múzeum, 1987, pp.353-363.

Kerny T. Szent László tiszteletének kutatástörténete (1977-2007). Arrabona, 2008, vol.46, iss. 1, pp. 15-35. 
Klaniczay G. A Szent László kultusz kialakulása. Nagyvárad és Bihar a korai középkorban. Tanulmányok Biharország történetéröl. Nagyvárad, Varadinum, 2014, pp.7-39.

Klaniczay G. Holy Rulers and Blessed Princesses. Dynastic Cults in Medieval Central Europe. Cambridge, Cambridge University Press, 2000, 518 p.

Klaniczay G. Sainteté royale et sainteté dynastique au moyen âge. Traditions, métamorphoses et discontinuités. Les Cahiers du Centre de Recherches Historiques, 1989, iss. 3, pp. 69-80.

Kondor M. A királyi kúria bíróságaitól a kancelláriáig. A központi kormányzat és adminisztráció Zsigmondkori történetéhez. Századok, 2008, vol. 142, iss.2, pp.403-436.

Körmendi T. Az Osl nemzetség címerváltozásai a középkorban. Turul, 2010, vol. 83, iss. 1, pp. 3-24.

Kozlowski S. K. Trecento Panel Painting between the Courts of Naples and Hungary. A Hypothesis for Simone Martini's Saint Ladislaus and a Painting of Christ on the Cross. Convivium, 2019, vol. 6, iss. 2, pp. 78-97.

Kurcz Á. A lovagi kultúra Magyarországon a 13-14. században. Budapest, Akadémiai Kiadó, 1988, 314 p.

Kušnierová E. Stredoveká nástenná malba z Rákoša. Pamiatky a múzeá, 1995, vol. 2, iss. 44, pp. 1-17.

Lángi J., Mihály F. Erdélyi falképek és festett faberendezések, vol.2. Budapest, Állami Műemlékhelyreállitási és Restaurálási Központ, 2004, 120 p.

László Gy. A Szent László-legenda középkori falképei. Budapest, Tájak-Korok-Múzeumok Egyesület, 1993, $257 \mathrm{p}$.

Lővei P. Anjou-magyar síremlékek és címeres emlékek a Nápolyban. Ars Hungarica, 1998, vol.26, iss. 1, pp. $18-51$.

Lukács M. Az altomontei Szent László kép története. Acta Historica Hungarica Turiciensia, 2005, vol. 7, iss. 1, pp. 198-201.

Marosi E. Der grosse Münzsiegel der Königin Maria von Ungarn: Zum Problem der Serialität Mittelalterlicher Kunstwerke. Acta Historiae Artium Academiae Scientiarum Hungaricae, 1982, vol. 28, iss. 1-2, pp. 3-22.

Marosi E. Der heilige Ladislaus als ungarischer Nationalheiliger. Bemerkungen zu seiner Ikonographie im 14.-15. Jh. Acta Historiae Artium Academiae Scientiarum Hungaricae, 1987-1988, vol.33, iss. 3-4, pp. 211-256.

Michalsky T. Memoria und Repräsentation: die Grabmäler des Königshauses Anjou in Italien. Gottingen, Vandenhoeck \& Ruprecht, 2000, 446 p.

Michalsky T. Tombs and the Ornamentation of Chapels. Artistic Centers of the Italian Renaissance. Naples. Cambridge, Cambridge University Press, 2017, pp. 233-277.

Modena S. 'Tituli', iscrizioni e motti: il francese esposto in Italia fra XIV e XV secolo. Francigena, 2016, iss. 2, pp. 153-199.

Nagy I. Magyarország családai czimerekkel és nemzékrendi táblákkal, vol.1. Pest, Kiadja Friebeisz István, $1857,312 \mathrm{p}$.

Năstăsoiu D. Gh. A New sancta et fidelis societas for Saint Sigismund of Burgundy: His Cult and Iconography during the Reign of Sigismund of Luxemburg. The Hungarian Historical Review. Acta Historica Academiae Scientiarum Hungaricae, 2016, vol. 5, iss. 3, pp. 587-617.

Năstăsoiu D. Gh. Nouvelles représentations de la Légende de Saint Ladislas à Crăciunel et Chilieni. Revue Roumaine d'Histoire de l'Art. Série Beaux-Arts, 2008, vol. 45, pp. 3-22.

Năstăsoiu D.-Gh. Between Personal Devotion and Political Propaganda: Iconographic Aspects in the Representation of the sancti reges Hungariae in Church Mural Painting $\left(14^{\text {th }}\right.$ Century - Early-16 ${ }^{\text {th }}$ Century). PhD diss. Budapest, Central European University, 2018, 542 p.

Norman D. Sanctity, Kingship and Succession: Art and Dynastic Politics in the Lower Church at Assisi. Zeitschrift für Kunstgeschichte, 2010, vol. 73, iss. 3, pp. 297-334.

Pedroni L. Le pseudo-cariatidi del sepolcro di Ladislao di Durazzo. Virtù regali, rappresentazione e ideologia. Iconographica, 2018, iss. 17, pp. 104-116.

Plekanec V., Haviar T. Gotický Gemer a Malohont. Italianizmy v stredovekej nástennej malbe. = Gothic Gemer and Malohont. Italianizing in Medieval Wall Painting. Martin, Vydavatel'stvo Matice slovenskej, Arte Libris, 2010, $191 \mathrm{p}$.

Prokopp M. Gömöri falképek a XIV században. Müvészettörténeti Értesitő, 1969, vol. 18, iss. 2, pp. 128-148. Prokopp M. Italian Trecento Influence on Murals of East Central Europe, Particularly Hungary. Budapest, Akadémiai Kiadó, 1983, 199 p. 
Prokopp M. Középkori freskók Gömörben. Somorja, 2002, 94 p.

Prokopp M. Magyar szentek az itáliai trecento festészetben. Magyar szentek tisztelete és ereklyéi. Esztergom, Keresztény Múzeum, 2000, pp. 25-35.

Prokopp M. Simone Martini Szent László képe Altomonte-ben, Szent László és Somogyvár. Szent László és Somogyvár. Tanulmányok a 900 éves somogyvári bencés apátság emlékezetére, vol. 1. Kaposvár, Somogy Megyei Múzeumok Igazgatósága, 1992, pp. 163-170.

Ritzerfeld U. Johanna I. und die Incoronata in Neapel. Weiblicher Herrschaftsanspruch in der Kirche der 'Regina Dolorosa'. Mitteilungen des Kunsthistorischen Institutes in Florenz, 2017, vol. 59, iss. 3, pp. 283323.

Schofield Ph. R. Seals and Their Context in the Middle Ages. Oxford, Oxbow Books, 2015, 208 p.

Skalská M. Rod Bubekovcov z Plešivca do začiatku 15. storočia. Historický zborník, 2010, vol.20, iss.2, pp. $19-45$.

Solymosi L. Szent László király sírja, kultusza és szentté avatása. Szent király, lovágkirály. A Szent Lászlóherma és koponyaereklye vizsgálatai. Győr, Győri Hittudományi Főiskola, 2017, pp. 16-39.

Szakács B.Zs. Saints of the Knights - Knights of the Saints: Patterns of Patronage at the Court of Sigismund. Sigismund von Luxemburg: ein Kaiser in Europa. Tagungsband des internationalen historischen und kunsthistorischen Kongresses in Luxemburg, 8.-10. Juni 2005. Mainz, Philipp von Zabern, 2006, pp.319-330.

Szakálos É. A pelsőci templom 14. századi falképei. Ars Hungarica, 2013, vol. 39, iss. 2, pp. 212-219.

Szentmártoni Szábó G. Kanizsai János esztergomi érsek korabeli portréja és címere Bázelban. Turul, 2011, vol. 81, iss. 4, pp. 137-139.

Szovák K. The Image of the Ideal Knight in Twelfth-century Hungary. Remarks on the Legend of St Ladislas. Kings and Kingship in Medieval Europe. London, King's College and Centre for Late Antique and Medieval Studies, 1993, pp. 241-264.

Tihányiová M. A Pelsőci Bebek család temetkezési helyei és síremlékei. Történelem és Muzeológia Internetes Folyóirat Miskolcon, 2018-2019, vol. 5, iss. 1-2, pp. 130-143.

Tihányiová M. A pelsőci Bebekek. Egy nemesi család felemelkedése és bukása. Rozsnyó, Georgius Bebek Polgári Társulás, 2019, 160 p.

Tihányiová M. Dejiny Kamenian s dôrazom na ev. a. v. Kostol. Najnovšie poznatky z výskumov stredovekých na Gotickej ceste - Zborník Gotiská cesta, 2016, iss. 2, pp.37-50.

Togner M. Stredoveká nástenná malba v Gemeri. Bratislava, Tatran, 1989, 208 p.

Valter I. A tornaszentandrási r. k. templom kutatása. A Herman Ottó Múzeum Évkönyve, 1980, iss. 19, pp. $99-130$.

Vauchez A. 'Beata stirps': sainteté et lignage en Occident aux XIIIe et XIVe siècles. Famille et parenté dans l'Occident médiéval. Rome, École Française de Rome, 1977, pp.397-406.

Verzár F. Régi magyar vonatkozások Bázelben. Debreceni Szemle, 1931, iss. 5, pp.310-314.

Vitolo P. 'Miles Christi': san Ladislao d'Ungheria tra mito cavaleresco e culto dinastico. Il ciclo pittorico all'Incoronata di Napoli. La battaglia nel Rinascimento meridionale. Moduli narrativi tra parole e immagini. Rome, Viella, 2011, pp.43-56.

Whatley L. A Companion to Seals in the Middle Ages. Leiden, Brill, 2019, 431 p.

Статья поступила в редакцию 19 августа 2020 г. Рекомендована в печать 25 мая 2021 г.

Received: August 19, 2020 Accepted: May 25, 2021 